Wildlife, Science, and the National Parks, 1920-1940

Author(s): Thomas R. Dunlap

Source: Pacific Historical Review, Vol. 59, No. 2 (May, 1990), pp. 187-202

Published by: University of California Press

Stable URL: http://www.jstor.org/stable/3640056

Accessed: 18/02/2014 15:51

Your use of the JSTOR archive indicates your acceptance of the Terms \& Conditions of Use, available at http://www.jstor.org/page/info/about/policies/terms.jsp

JSTOR is a not-for-profit service that helps scholars, researchers, and students discover, use, and build upon a wide range of content in a trusted digital archive. We use information technology and tools to increase productivity and facilitate new forms of scholarship. For more information about JSTOR, please contact support@ jstor.org. 


\title{
Wildlife, Science, and the National Parks, 1920-1940
}

\author{
THOMAS R. DUNLAP \\ The author is a member of the history department \\ in Virginia Polytechnic Institute and State University.
}

The values Americans have attached to national parks have been changing as long as the parks have been in existence, reflecting and sometimes anticipating society's shifting ideas about nature and its place in our culture. Nowhere has this been more pronounced than with regard to animals. The earliest park acts provided for protection for wildlife and some of the first game protection laws were applied to the parks, but until well into the twentieth century, park officials cared for only a few species, ignoring and even killing the others. Now wild animals are among the parks' major attractions, and the preservation of all species is an important part of their mission. The change came between the two world wars, when the new National Park Service broke with practices that went back to the earliest years of the parks. Declaring that it had a mission to save all native animals and the web of relationships among plants, animals, and land, the Park Service began to protect the formerly hunted predators,

Much of the research for this article was done with the financial support of the National Sciences Foundation (Grant Number SES 8319362) and the Virginia Tech history department. I owe a more personal debt to my colleagues, who criticized a seminar paper and earlier versions of this article. 
saving endangered species, and eliminating foreign animals from their parks. ${ }^{1}$

A small group, mainly mammalogists, was behind this change. Using the concepts of the new field of animal ecology and the prestige of science, they gave a different meaning to the idea of an authentic, primitive natural landscape. Their ideas had implications for wildlife everywhere; they first affected the parks because it was there they could most easily bring scientific information and preservation sentiment to bear on actions. The Park Service was small, nonpolitical, committed to guidance by experts, and just beginning to take on institutional form. Employed in the Service's Wild Life Division (established 1933), the scientists could work for the preservation of all species in an atmosphere free of longestablished bureaucratic restraints and more conducive to seeing new ideas transformed into policy.

In the late nineteenth century Americans began establishing national parks to preserve what they valued in naturethe spectacular scenery of mountains, chasms, and geological freaks. Though park acts provided for the protection of wild animals as well as scenery, for park officials wildlife meant only those creatures that added to the parks' appeal. The ideal animal was large and stood around in groups in the

1. The role of scientists and scientific ideas in the nature conservation and preservation movements of twentieth-century America has not been investigated in any depth, nor have historians traced in any detail the changing place of wildlife in popular ideas about nature or the influence of field biology and ecology on these ideas. Alfred Runte, National Parks: The American Experience (2nd ed., Lincoln, 1987), chapters 6 and 7, deals with the administrative and policy aspects of changing views in the Park Service. On wilderness, see Roderick Nash, Wilderness and the American Mind (3d ed., New Haven, 1982), chapter 13. Donald Worster's Nature's Economy (San Francisco, 1977) deals with scientific and popular ideas, but in such a wide context that individual scientists and their ideas vanish. He does not, in any event, concentrate on wildlife and its meaning as part of nature. Peter Mattiessen's Wildlife in America (New York, 1959) provides a popular treatment, but it is not well based in historical sources. The same might be said of Barry Holstun Lopez, Of Wolves and Men (New York, 1978). There is a large literature on hunting, but this is hardly adequate for wildlife. The best recent studies on evolving attitudes toward animals are Keith Thomas, Man and the Natural World (New York, 1983) and James Turner, Reckoning with the Beast (Baltimore, 1980), but these deal with the general relation of animals to humans, not of wild animals to humans and human conceptions of nature. 
open-posing nobly in the middle distance against a background of mountain peaks - or entertained tourists with its "cute" antics. "Management" meant encouraging these species, killing their "enemies," and ignoring the others. Yellowstone superintendents, for example, kept the buffalo near the roads and stampeded them to show prominent visitors the "thundering herd." They fed elk through the winter and set up feeding stations for the bears at the park's garbage dumpswith bleachers for the tourists. ${ }^{2}$ They shot, trapped, and poisoned wolves, coyotes, and mountain lions. "Up to about 1930," notes an in-house Park Service history, "a great majority of people, including National Park Service officials, took it for granted that complete protection of wildlife involved elimination or drastic control of all predators. The term 'extermination of predators' appears often in... official business...."3 No one thought of the parks as preserves for all species in a balance dictated by natural forces.

People thought instead in terms of "good" and "bad" animals and of encouraging the good ones and getting rid of the bad ones. Even the Audubon Society recommended that bird-killing hawks be shot on sight. Its only reservation about public campaigns against the hawk was that most people could not distinguish the "good" from the "bad" raptors. ${ }^{4}$ The Forest Service killed predators in reserves (like the Kaibab National Forest) to build up the deer herd, and in 1918 Aldo

2. Until the late 1920s, when the level of injuries and death forced a more cautious policy, park officials treated bears as tourist attractions. In 1922 Horace Albright, then superintendent of Yellowstone and later head of the Park Service, posed at a picnic table with several of his furry friends. See Horace M. Albright, The Founding of the National Park Service (Salt Lake City, 1985), 182. Runte, National Parks, 168-169. Even today bear policy is not, with the exception of the grizzlies of Yellowstone, "wildlife policy," but "nuisance animal control," a matter of protecting people and property.

3. C. C. Presnall, "Discussion of Service Predator Policy" (1939), in "Condensed Chronology of Service Predator Policy," file 719, entry 7, Records of the National Park Service, Record Group 79, National Archives, Washington, D.C. (cited hereafter as RG 79, National Archives). Chronology and information on park service predator policy is found, unless otherwise attributed, in this file.

4. The Audubon magazine-Bird-Lore to 1940, Audubon thereafterpresents a fascinating picture of changing attitudes prior to 1940 . On changes, see also Thomas R. Dunlap, Saving America's Wildlife (Princeton, N.J., 1988), chap. 6. 
Leopold, editing the Pine Cone for the New Mexico Game Protective Association, called for getting the last predator scalp in the state. ${ }^{5}$ In 1915 Congress had authorized the Bureau of Biological Survey to assist ranchers in controlling predatory animals, and by the mid-1920s the agency had killed the last breeding wolves in the West and was hunting down the stragglers. Even people who liked predators were often resigned to seeing them killed off. Their deaths were the price of progress. ${ }^{6}$

By the 1920s a few people began to see value in the despised varmints and to urge their preservation. The first organized protests came from academic zoologists, mainly westerners, who took aim at the Biological Survey's predator control program. At the 1924 meeting of the American Society of Mammalogists, a small group-Joseph Dixon, Lee Dice, Harold Anthony, and C. C. Adams-claimed that the Survey's liberal use of poison was wiping out local wildlife populations, threatening whole species, and taking an unacceptable toll on nontarget animals. They did not object to control, even to poisoning (this was not a protest on "environmental" or humane grounds), but to unnecessary slaughter. ${ }^{7}$ The debate, which went on until 1931, centered around reconciling preservation with progress; "stock-killers," everyone admitted, could not be allowed where sheep and cattle grazed. The parks, which had, after all, been set up to preserve wild America, seemed to be the solution. ${ }^{8}$

5. The Kaibab has been extensively treated. Thomas R. Dunlap, "That Kaibab Myth," Journal of Forest History, XXXII (1988), 60-68, is the latest review. On Leopold, see Susan Flader, Thinking Like a Mountain (Columbia, Mo., 1974).

6. See, for instance, Ernest Thompson Seton's "The King of Currumpaw: A Wolf Story," Scribner's XVI (Nov. 1894), 618-626, reprinted as "Lobo, King of the Currumpaw," in Seton, Wild Animals I Have Known (New York, 1898), and comments in Seton, Lives of Game Animals (1925-1928; Boston, 1953). Theodore Roosevelt felt the same way; this refrain runs through The Wilderness Hunter: The Works of Theodore Roosevelt, National Edition (New York, 1926), Hunting Trips of a Ranchman (New York, 1885), and Hunting the Grisly and Other Sketches (New York, 1893).

7. Thomas R. Dunlap, "Values for Varmints: Predator Control and Environmental Ideas, 1920-1939," Pacific Historical Review, LIII (1984), 141-161. For a contrary view of the significance of this episode, see Worster, Nature's Economy, chap. 13.

8. Dunlap, "Values for Varmints," 147-158. 
Joseph Grinnell, director of the Museum of Vertebrate Zoology in Berkeley, California, led the opposition to predator control and was a strong voice for wildlife preservation. Born in 1877 in the Indian Territory (his father was a doctor at an Indian agency post), he had grown up on the reservations and in Pasadena, California, studying the land as an amateur naturalist at a time when it was rapidly changing. After 1908, when he became head of the new Museum of Vertebrate Zoology, he participated in numerous collecting expeditions that added a valuable perspective to his impressions about what stock raising, mining, and irrigation were doing to the land. ${ }^{9}$ About the same time, he started faunal studies in Yosemite to establish the distribution and abundance of animals in the region. He realized that the West he had known was vanishing, and he wanted to save it.

Grinnell's sentiments were becoming more common; even the agents of progress were uncomfortable with their role. Vernon Bailey, the Survey's chief naturalist, had been involved in predator control since the agency's surveys of national forests in 1907 , but he said of the wolves he was killing: "[f]ew animals are more devoted to their home life, braver, or more intelligent. Yes, they were cruel killers, but not half as cruel as we have been." ${ }^{10}$ Stanley Paul Young, who made his Survey career in predator and rodent control, thought wolves wonderful creatures. Both he and Bailey wanted to keep them, but in areas without livestock. ${ }^{11} \mathrm{~A}$ few

9. See, for example, Grinnell to C. Hart Merriam, Nov. 27, 1907, in Rescued Correspondence, 1907, box 78, W. L. McAtee Papers; Joseph Grinnell, "The Methods and Uses of a Research Museum," Popular Science Monthly, LXXVII (Aug. 1910), 163-169, reprinted in Joseph Grinnell's Philosophy of Nature (1943; Freeport, N.Y. 1968). On feelings about the transformation of the West, see Lee Clark Mitchell, Witnesses to a Vanishing America: The Nineteenth Century Response (Princeton, N.J., 1981). The use of science in this enterprise was not unique. As Grinnell was mapping the distribution of cactus wrens and ground squirrels in California, Alfred Kroeber and his students were collecting the scattered fragments of Native American languages, rituals, and beliefs, intellectually reconstructing the world the whites were destroying.

10. Vernon Bailey, "The Home Life of the Big Wolves," Natural History, XLVI (Sept. 1940), 120-122.

11. Vernon Bailey, "Wolves in Relation to Stock, Game, and the National Forest Reserves," Forest Service Bulletin 72 (Washington, D.C., 1907), box 5, folder 12, Vernon Bailey Papers, Smithsonian Archives, Smithsonian Institution, 
went further. In 1929, Olaus Murie, then a predator and rodent control supervisor for the Bureau of Biological Survey, confessed to one of his colleagues that he was "very fond of native mammals, amounting almost to a passion," and that he "would make considerable sacrifice for the joy of animal companionship and to insure that other generations might have the same enjoyment and the same opportunity to study life through the medium of the lower animals." The Survey's predator control operations, he said, had no scientific backing, "and to tell the truth I could not see that the queries of the [mammalogists] had been met." 12

The debate over poisoning crystallized sentiment in the Park Service-or provided an excuse for action. Certainly park officials were ready. At their annual conference in 1925 the park superintendents reduced the money that rangers received from the sale of pelts and cut the list of predators to three species: wolves, coyotes, and cougars. Three years laterfollowing a speech by Joseph Grinnell - they passed a resolution opposing trapping in the parks. In May 1931 Park Service Director Horace Albright pledged "total protection to all animal life," including predatory animals, which "have a real place in nature." They would be killed only where they were causing "actual damage" or threatening a species that needed special protection. Trapping would end and poison would be used only for rodent control in settled areas or emergencies. He proclaimed a wildlife mission that went well beyond the "scenic" ideal. "[A]Il animal life should be kept inviolate" and the parks should preserve "examples of the various inter-

Washington, D.C.; Stanley Paul Young, "The War on the Wolf," American Forests, XLVIII (Dec. 1942), 574. See also Stanley Paul Young and Edward A. Goldman, The Wolves of North America (1944; New York, 1964); Stanley Paul Young and H. H. T. Jackson, The Clever Coyote (Washington, D.C., 1951); Stanley Paul Young, The Last of the Loners (New York, 1970). The same holds true even for a later generation. See Charles L. Cadieux, Coyotes: Predators and Survivors (Washington, D.C., 1983).

12. Murie to A. Brazier Howell, May 7, 1931, Department of Mammalogy, American Museum of Natural History, New York; Murie to W. C. Henderson, Jan. 9, 1931, box 265, Olaus Murie Papers, Denver Conservation Library, Denver, Colo. See also K. C. McMurray to J. N. Darling (head of the Survey), Dec. 18, 1934, in file: Predatory-States, Michigan, General Files, Division of Wildlife Services, Records of the U.S. Fish and Wildlife Service, Record Group 22, National Archives, Washington, D.C. 
esting North American mammals under natural conditions for the pleasure and education of the visitors and for the purpose of scientific study." 13

Albright echoed the sentiments of the wildlife experts who were finding a place, and influence, in the Park Service. No one had had direct responsibility for park animals in 1928, when George Wright, an independently wealthy parttime ranger, proposed and offered to pay for a survey of park animals and their habitat. The Service agreed and the results of the two-year study (by Wright, Ben H. Thompson, and Joseph Dixon) were so impressive that in 1931 the agency made Wright a field naturalist and, two years later, chief of the new Wild Life Division. Animal ecology and concern for the preservation of all animals were a part of the new bureau's ethos. As a forestry student at the University of California, Wright had taken a minor in vertebrate zoology under Grinnell and spent a summer making life history studies of the fauna of Mt. McKinley (now Denali) National Park with Grinnell's assistant, Joseph Dixon. ${ }^{14}$ Three other members of the staff had worked or been trained at the Museum of Vertebrate Zoology, and another Grinnell student, Harold Bryant, had been on the committee recommending establishment of a permanent wildlife branch (and as head of the park education program would spread the gospel to visitors). ${ }^{15}$ Carl P. Russell, who became chief after Wright died in a car accident in December 1935, studied under Lee Dice (also a Grinnell

13. Presnall, "Condensed Chronology," file 719, entry 7, RG 79, National Archives; Horace M. Albright, "The National Park Service's Policy on Predatory Animals," Journal of Mammalogy, XII (May 1931), 185-186.

14. Ben H. Thompson, "George M. Wright, 1904-1936," George Wright Forum, I (Summer 1981), 1-4.

15. The people associated with the Museum of Vertebrate Zoology included Joseph Dixon, E. Lowell Sumner, Adrey E. Borell, Theodore H. Eaton, Jr. All were listed on the first page of the memo that the Division in 1935 sent to the Bureau of Biological Survey asking that they be put on the mailing list for the Survey's new bibliographical guide to wildlife management research. Grinnell's commitment to ecology and the interests of his students may best be judged from his correspondence in the Museum of Vertebrate Zoology (hereinafter cited as MVZ), Berkeley. These collections cited by permission of Dr. David Wake, director, MVZ. Alfred Runte, personal communication, has suggested that while Grinnell's interest in wildlife was constant, his enthusiasm for ecological concepts developed by his students may have varied directly with the credit they gave him for his inspiration. 
student) who had established a pioneer program in animal ecology at the University of Michigan. Russell's assistant, Victor Cahalane, had worked with Dice at the Cranbrook Institute of Science, and the man whose work was crucial to the defense of natural management of all species, Adolph Murie, had taken his Ph.D. under Dice at the University of Michigan in 1929.

Wright immediately published his survey as the first of a new monograph series - "Fauna of the National Parks." 16 All species, it said, "should be preserved, for each is the embodied story of natural forces which have been operative for millions of years and is therefore a priceless creation." Predators were included, for they find in the parks "their only sure haven... [and] are given opportunity to forget that man is the implacable enemy of their kind, so that they lose their fear and submit to close scrutiny." Boundaries should be adjusted to make each park an ecological unit where native wildlife should be saved or restored and exotics curbed or eliminated. Park officials needed to educate the public to appreciate wildlife in its natural setting, to thrill to the lone bear in the forest rather than the group at the garbage dump. ${ }^{17}$

Events were even then reinforcing Wright's case. The Yellowstone elk herd had been a problem since the early part of the century. Ranchers protested that the swollen herd was devouring range grasses outside the park; the annual slaughter as the migrating animals left the park appalled many; and no one liked the occasional, spectacular die-offs during bad winters. ${ }^{18}$ In the winter of $1924-1925$ the protected deer in the Kaibab National Forest, on the north rim of the Grand Canyon, began dying in the thousands because of disease and starvation. Herds across the country, many of them in the

16. George M. Wright, Joseph S. Dixon, Ben H. Thompson, "Fauna of the National Parks of the United States," Fauna Series Number One, U.S. Dept. of the Interior (Washington, D.C., 1933). On policy, see "Report of the U.S. National Park Service," Sen. Rep. 1203, 76 Cong., sess. (1940), 350-352; Victor H. Cahalane, "The Evolution of Predator Control Policy in the National Parks," Journal of Wildlife Management, III (July 1939), 229-237; and file 720, entry 7, RG 79, National Archives.

17. Wright et al., "Fauna of the National Parks," 2, 54-56.

18. Douglas B. Houston, The Northern Yellowstone Elk: Ecology and Management (New York, 1982). 
populated Northeast, went through the same cycle, and the spectacle of dead deer and stripped forests was a stark challenge to the idea of complete protection. ${ }^{19}$ In Game Management (1933), Aldo Leopold had come far enough from his earlier views to suggest that predator control had to be proved useful in each instance; it could not be assumed to be needed or helpful. ${ }^{20}$ As the decade went on his views would shift even further toward an ideal of restoring nature's harmony in the parks. Others would slowly follow his lead.

The Wild Life Division's scientists, though, did not argue, on the evidence of disasters, that all wildlife should be preserved, still less did they use aesthetic arguments about the beauty of nature. They grounded their appeals on scientific studies, justifying their love of wild animals with ecological theory and field research that saw each species as part of a system. Niches, ecosystems, food chains, and the pyramid of numbers replaced vague ideas about the "balance of nature"; quantitative studies undermined myths of "bad" animals. This kind of defense would not have been possible earlier, for it depended upon ideas just being developed. Victor Shelford's Animal Communities of North America, the first attempt to organize animal communities on ecological principles, had been published in 1917, and Charles Elton's Animal Ecology, which popularized the ideas of niche and food chain and provided a research program for a generation of scientists, only a decade later. ${ }^{21}$

The new defense of nature can be seen by comparing the studies that Adolph Murie did for the Park Service on the coyotes of Yellowstone (1937-1939) with those of his brother Olaus conducted for the Biological Survey on the coyotes of Jackson Hole, Wyoming (1927-1932). ${ }^{22}$ The coyote popula-

19. On these irruptions see Aldo Leopold, Lyle K. Sowls, and David L. Spencer, "A Survey of Over-Populated Deer Ranges in the United States," Journal of Wildlife Management, XI (April 1947), 162-177.

20. Aldo Leopold, Game Management (New York, 1933), 252.

21. Victor Shelford, Animal Communities of North America (Chicago, 1917); Charles Elton, Animal Ecology (1927; London, 1966).

22. Olaus J. Murie, "Food Habits of the Coyote in Jackson Hole, Wyo.," U.S. Dept. of Agriculture, Circular 362 (Washington, D.C., 1935); Adolph Murie, "Ecology of the Coyote in the Yellowstone," Fauna Series Number Four, U.S. Dept of the Interior (Washington, D.C., 1940). 
tions overlapped, the areas were similar, both studies began in response to complaints that predators were killing off the more desirable species, and both aimed to see what effect coyotes had on elk under wilderness conditions. Even their conclusions were the same: individual elk were vulnerable, the population was not. ${ }^{23}$ Their methods, though, were very different. Olaus analyzed stomach contents and scats to determine the "Food Habits of the Coyotes of Jackson Hole, Wyoming." Elk, he pointed out, were a small part of the coyotes' diet (and probably came from carrion not kills). This suggested that elk and coyotes could live together. Adolph looked at many factors - weather, food, disease, cover, and historical patterns of wildlife abundance. He counted elk, studied calf survival, and reported on coyote behavior and the animal's relationships with species ranging from bison and moose to porcupines and squirrels. His work was as comprehensive as the title: Ecology of the Coyote in the Yellowstone, and his conclusions about the elks' ability to survive grounded in a different theory. The change in methods was even more apparent in Adolph's study of the wolves and Dall sheep of Mt. McKinley National Park (1939-1941), the first ecological study of a large predator and its prey population. There he tested the argument that predators selected old, weak, ill, or otherwise defective individuals by collecting over eight hundred sheep skulls. He compared the living and dead populations in terms of age and sex, and looked at the numbers showing signs of disease or injury. He watched wolves at their dens over two summers, providing the first extensive observations on their behavior in the wild. ${ }^{24}$

23. Both reports, to continue the similarities, raised opposition in the agencies they were intended for. Olaus's colleagues in predator and rodent control thought he had not sufficiently emphasized coyotes' appetite for mutton. Park Service officers who thought that "innocent" animals needed protection wanted to fire Adolph. See box 264, miscellaneous P file, Olaus Murie Papers, Conservation Center, Denver Public Library, Denver, Colo.; and box 83, W. L. McAtee Papers, Library of Congress, Manuscript Division, for comments on Olaus's paper. On Adolph's troubles, see Olaus Murie to Harold E. Anthony, Dec. 5, 1945, Murie file, Dept. of Mammalogy, American Museum of Natural History; Olaus Murie to Carl L. Hubbs, July 30, 1946, box 361, folder 7, Adolph Murie Papers, Conservation Center, Denver Public Library, Denver, Colo.; file 720, entry 7, RG 79, National Archives.

24. Adolph Murie, "The Wolves of Mt. McKinley," Fauna Series Number 
It was not a matter of an unsophisticated approach versus a sophisticated one; Olaus worked under the direction of the Survey's W. L. McAtee, for years head of the Survey's Division of Food Habits Research, and his studies reflected faithfully the best methods of scat and food analysis available. Nor did the brothers have different ideas about wildlife preservation. Their research was different because they were of different professional generations, with different training and conceptual tools. Olaus, born in 1889, had graduated from college in 1912. He worked on field and museum jobs for a few years before joining the Biological Survey. He got an M.S. (from the University of Michigan in 1927), but he did it at his brother's urging, and the work was clearly an interlude in his career in the Biological Survey. His appreciation of ecology came later, when he was studying elk with Adolph. ${ }^{25}$ Adolph, ten years younger, finished college in 1923, and though he did some natural history work-including a faunal survey in Alaska with Olaus in 1922-1923-he received a professional education in wildlife ecology under Dice at Michigan, where he learned concepts and research methods developed since his brother had left school.

By the mid-1930s the Park Service had ended most predator killing and was moving toward management to achieve a natural state; it needed studies like Adolph's to fend off the considerable opposition to saving predators in the parks. ${ }^{26}$ Ranchers complained that the parks were now sanctuaries for "stock-killers"; hunters were concerned about "their" trophies;

Five, U.S. Dept. of the Interior (Washington, D.C., 1944). On the importance of this work, see the dedication of L. David Mech's The Wolf: The Ecology and Behavior of an Endangered Species (Garden City, N.Y., 1970). Durward Allen, an eminent wildlife biologist and Mech's teacher, confirmed Mech's views in a personal communication to the author.

25. On the relationship of the Muries, I am indebted to Professor Jim Glover. On ecology, see Olaus Murie to Marcus Ward Lyon, March 30, 1935, Murie file, Dept. of Mammalogy, American Museum of Natural History, New York.

26. Cahalane, "Evolution of Predator Control Policy." On the partial exception, in Denali National Park (formerly Mt. McKinley), see Samuel J. Harbo, Jr., and Frederick C. Dean, "Historical and Current Perspectives on Wolf Management in Alaska," in Ludwig N. Carbyn, ed., "Wolves in Canada and Alaska," Canadian Wildlife Service Report Series Number 45 (Ottawa, 1983), 51-64. 
and even some staunch park defenders were baffled by the idea of saving "vermin." In the late 1930s Horace Albright, by then retired from the Park Service, clearly thought that things had gone too far. Coyotes, he declared, should be reduced or eliminated. Visitors never saw them and they were worthless. "I find," he wrote in 1937, "that the impression is quite widespread that the National Association of Audubon Societies and perhaps other organizations are more interested today in saving the predatory species of birds and mammals than giving reasonable consideration to the species that are regarded as very important by the general public." He hoped that the Park Service would not take this attitude. ${ }^{27}$ But it did, justifying the new policy by scientific studies describing all species as functional parts of a natural system.

The Division's point of view involved more than just saving the despised "varmints," more even than preserving natural systems. The scientists wanted a particular kind of natural system-North America as it had been before the whites came-and to get this they pushed for the elimination or curbing of introduced species. This was less controversial but almost as novel as preserving predators. People had been importing and establishing new plants and animals since the first days of settlement. In the late nineteenth century there had been a flood of exotics. Homesick European immigrants imported songbirds from their native lands; the rich stocked estates with game animals and birds from around the world; and hunters set out new species for sport. Texas and California went through a "Mediterranean" phase, and California had its Australian days as well. ${ }^{28}$ Nature was to be reshaped for human convenience and delight.

A reaction occurred in the 1890 s, in part the result of

27. Albright to A. E. Demaray, Nov. 24, 1937, file 720, entry 7, RG 79, National Archives.

28. See, for example, Robin Doughty, Wildlife and Man in Texas (College Station, Tex., 1983); T. S. Palmer, "The Danger of Introducing Noxious Animals and Birds," in U.S. Dept. of Agriculture, Yearbook of Agriculture, 1898 (Washington, D.C., 1899), 87-110; and John C. Phillips, "Wild Birds Introduced or Transplanted in North America," U.S. Dept. of Agriculture, Bulletin 61 (Washington, D.C., 1928); Woodbridge Metcalf, Introduced Trees of Central California (Berkeley, 1968). 
disastrous introductions like the starling but also fueled by romanticism and nationalism that sought to preserve the pioneer experience. Grinnell's paean to the game birds of California is typical. "Conserve our native species! There are none whose qualities are superior: they are part of the natural heritage of our land, and have been serviceable in the past; we are responsible for their preservation." ${ }^{29}$ By the 1920 s debate was far enough advanced that John Phillips, reviewing the record of game bird introductions into the United States, could refer to two schools of thought, "widely at variance. One of these, the conservative, represented by such eminent naturalists as Joseph Grinnell of California and many others, believes in preserving at all costs the present or rather the original status of native birds and harmless mammals, and points out the great dangers incurred in the importation of species in other parts of the world, and especially the danger of spreading new diseases." The other would try anything without considering the dangers of the suitability of the species to the country. (Phillips recommended a middle course that avoided both extremes. $)^{30}$

As with predator control, advocates of native wildlife and native ecosystems (a word just coming into use) saw the parks as a sanctuary. In 1930 the Service took the first steps toward that goal; Albright sent out a notice calling for the preservation of native flora and fauna. Superintendents, he stated, should eliminate or curb nonnative forms and take steps to see that there were no introductions. ${ }^{31}$ A decade later the Service told a U.S. Senate special committee on wildlife that: another phase of the Service program of wilderness protection is concerned with elimination of nonnative animals that at times have become introduced into various parks, often to the detriment of native fauna and flora. Any exotic species which has already become established in a park shall be either eliminated or held to a minimum provided complete eradication is not

29. Joseph Grinnell, Harold C. Bryant, and Tracy I. Storer, The Game Birds of California (Berkeley, 1918), 44.

30. Phillips, "Wild Birds," 5.

31. Albright to Superintendent and Concessionaires, Nov. 11, 1930, file 720, entry 7, RG 79, National Archives. 
feasible, and the possible invasion of the parks by other exotics shall be anticipated and steps taken to guard against the same. ${ }^{32}$

The parks were to be refuges not just for nature, but for nature as it had been when the Europeans arrived. ${ }^{33} \mathrm{~A}$ corollary was the preservation of native species. In 1930 Wright began a campaign for the trumpeter swan, and managed not only to protect the birds in Yellowstone but also to enlist the Biological Survey's help in creating a refuge (Red Rock Lakes Migratory Waterfowl Refuge) at the birds' breeding ground outside the park. The Service took more interest in the Yellowstone grizzlies, initiating a program that is now one of its most controversial. It also began shooting burros in the Grand Canyon to help the native wildlife. In still another move, it sought to increase public education on endangered species, in 1943 sponsoring a book, Fading Trails, to alert the public. ${ }^{34}$

The logical end of all this was a park in which wildlife would be the chief attraction and which would be managed to preserve the habitat in its "primitive" state. That was indeed one of the scientists' goals. Everglades, authorized as a national park in 1934, showed how public ideas were changing, but a better indicator was the Division's decade-long campaign for Isle Royale, the largest island in Lake Superior. The area had none of the spectacular displays of massed wildlife that made the Everglades a mecca for bird-watchers. It was, at best, an unspectacular northern forest. Nor was it pristine. Logged and mined in the nineteenth century, it was a maze of cut-over areas, mine dumps, and burned-out patches, with summer camps and fishing piers. Still, it could be restored and (because it was isolated) managed as an ecological unit. The scientists may have been enthusiastic because they knew it so wellC. C. Adams had surveyed it in 1904 and Adolph Murie had studied the island's moose population in the early 1930s. Michigan had suggested making it a park as early as 1930 and

32. Sen. Rep. 1203 , pp. 352, 362 .

33. The complexities and ambiguities in this definition have been part of park policy since.

34. Sen. Rep. 1203, 352-365, U.S. Dept. of the Interior, Fading Trails: The Story of Endangered American Wildlife (New York, 1943). On the grizzly controversy, see Alston Chase, Playing God in Yellowstone (Boston, 1986), an excellent example of the depth of emotion that the issue still rouses. 
the Wild Life Division pressed the case. In 1940 Congress finally authorized the park, and the Service had its (ecological) island. ${ }^{35}$

It is a long way from Yellowstone's geysers to the spruce forests of Isle Royale, from strychnine for predators to calls for reintroducing wolves, but the scientists traveled the roadand quickly. In twenty years, using ecological research that portrayed each species as part of a whole, and the whole as unique, irreplaceable, part of the American past, they changed the Park Service's policy toward animals and made preservation of all species a part of the agency's mission. A new public appreciation for wild animals and nature and the existence of the Wild Life Division were important (and the scientists helped form both). Still, the crucial element in the shift was the scientists' ability to use the cultural authority of science to define wilderness, to describe the romantic dream of the world as it had been in ways that could be converted to action on the ground. ${ }^{36}$

The strength of that dream became clear after World War II, as popular writing, movies, television, and public education carried ecological ideas to the public. More people came to see the world as a system and each species as an integral

35. The island became an important wildlife research area when wolves colonized it in the early 1950s. In 1957 the Park Service contracted with Purdue University biologist Durward Allen to study the wolves and moose. The project, which still continues, was the training ground for L. David Mech, the current chair of the Wolf Specialist Group of the Species Survival Commission of the International Union for the Conservation of Nature. Information gathered on Isle Royale has been used in the preservation plan for the eastern timber wolves in Minnesota. Durward Allen (personal communication, October 1988) thinks that the pack may not be viable; it is not breeding and may die out. L. David Mech, "The Wolves of Isle Royale," Fauna Series Number Seven, U.S. Dept. of the Interior (Washington, D.C., 1966); Durward L. Allen, Wolves of Minong: Their Vital Role in a Wild Community (Boston, 1979). On mainland wolf management, see wolf files, Office of Endangered Species, U.S. Dept. of the Interior, Washington, D.C.; and Eastern Timber Wolf Recovery Team, Recovery Plan for the Eastern Timber Wolf (Washington, D.C., 1978).

36. The development of this alliance is seen in the 1963 report of the Secretary of the Interior's Advisory Board on Wildlife Management on park wildlife, which placed ecology, ecosystem preservation, and native wildlife at the center of the parks' mission. Advisory Board on Wildlife Management, "Wildlife Management in the National Parks," in Wildlife Management Institute, Transactions of the Twenty-eighth North American Wildlife and Natural Resources Conference (Washington, D.C., 1963), 28-44. 
part of the whole, essential to its functioning. In 1935 when Harlow Mills, a Park Service naturalist, suggested that wolves and cougars be introduced into Yellowstone because they were "a vital part of the picture... which can never be the same in their absence," even the Wild Life Division gave that a quick burial..$^{37}$ The public, and in particular the stockman, would not understand. In 1980 the Northern Rocky Mountain Wolf Recovery Team, appointed under the Endangered Species Act of 1973 to produce a plan for the recovery of the population, found considerable opposition to reintroduction, but also much enthusiasm. When Canadian wolves crossed the border into Glacier National Park in 1986 the Park Service anxiously watched over them, and there have been suggestions that the Service has secretly reintroduced wolves into Yellowstone. ${ }^{38}$ The public has also come to demand the application of ecological ideas outside the parks. The Endangered Species acts of 1966, 1969, and 1973, the Marine Mammal Protection Act of 1972, and the 1973 Convention on Trade in Endangered Species are testimony to public interest in preserving as much of the ecosystem of the country as possible, even at the expense of some economic development. Laws are not always observed, and they may be changed, but current discussions on the preservation of wildlife in America are guided by ideas proposed and first implemented in the parks between the two world wars.

37. Harlow Mills to Ben H. Thompson, June 21, 1935, box 6, entry 34, RG 79, National Archives.

38. U.S. Fish and Wildlife Service, Northern Rocky Mountain Wolf Recovery Team, Northern Rocky Mountain Wolf Recovery Plan (Denver, 1980). See also Agency Review Draft, Revised Northern Rocky Mountain Wolf Recovery Plan (Denver, 1984); Chase, Playing God in Yellowstone, 129-141; Jim Robbins, "Wolves Across the Border," Natural History, XCV (May 1986), 6-15. 